\title{
SPONTANEOUS RECOVERY FROM NUTRITIONAL MACROCYTIC ANEMIA IN YOUNG SWINE FOLLOWING INITIAL ESTRUS
}

\author{
By SUSAN GOWER SMITH, RAYMOND REISER, AND GEORGE T. HARRELL \\ (From the Department of Medicine, Duke University School of Medicine, Durham, N. C., and \\ the Department of Animal Husbandry, North Carolina State \\ College, Raleigh, N. C.)
}

(Received for publication March 24, 1941)

Spontaneous recovery from a severe macrocytic anemia produced experimentally in young swine by a prolonged partial deficiency of the vitamin B-complex has not been reported previously. The present communication deals with such a study. or combination of synthetic factors has proven effective as the extrinsic factor.

Due to the varied hematopoietic response of different species to the same treatment, any study involving anemia demands care in the selection of

TABLE I

Correlation of age, sex, weight, diet and performance of all the animals

\begin{tabular}{|c|c|c|c|c|c|c|c|c|c|c|c|c|}
\hline \multirow{2}{*}{$\begin{array}{c}\text { Swine } \\
\text { number }\end{array}$} & \multirow{2}{*}{ Group } & \multirow{2}{*}{ Sex } & \multirow{2}{*}{$\begin{array}{c}\text { Initial } \\
\text { age }\end{array}$} & \multicolumn{3}{|c|}{ Weight } & \multirow{2}{*}{ Diet } & \multirow{2}{*}{$\begin{array}{l}\text { Time* un- } \\
\text { til severest } \\
\text { anemia }\end{array}$} & \multirow{2}{*}{$\begin{array}{l}\text { Time* un- } \\
\text { til cure of } \\
\text { anemiat }\end{array}$} & \multirow{2}{*}{$\begin{array}{c}\text { Type } \\
\text { of } \\
\text { anemia }\end{array}$} & \multirow{2}{*}{$\begin{array}{c}\text { Duration } \\
\text { of experi- } \\
\text { ment }\end{array}$} & \multirow{2}{*}{$\begin{array}{c}\text { Fate } \\
\text { of } \\
\text { animal }\end{array}$} \\
\hline & & & & Initial & Anemia & Final & & & & & & \\
\hline $\begin{array}{l}1 \\
2 \\
3 \\
4 \\
5\end{array}$ & $\begin{array}{r}\text { I } \\
\text { I } \\
\text { I-A } \\
\text { I-A } \\
\text { I-A }\end{array}$ & $\begin{array}{l}M \\
M \\
F \\
F \\
F\end{array}$ & $\begin{array}{c}\text { weeks } \\
14 \\
13 \\
21 \\
21 \\
21\end{array}$ & $\begin{array}{r}l b s . \\
46 \\
33 \\
85 \\
98 \\
92\end{array}$ & $\begin{array}{r}\text { lbs. } \\
52 \\
25\end{array}$ & $\begin{array}{r}\text { lbs. } \\
52 \\
25 \\
261 \\
268 \\
242\end{array}$ & $\begin{array}{l}\text { A } \\
\mathbf{A} \\
\mathbf{A} \\
\mathbf{A} \\
\mathbf{A}\end{array}$ & $\begin{array}{c}\text { weeks } \\
22 \\
8\end{array}$ & weeks & $\begin{array}{l}\text { Microcytic } \\
\text { Microcytic }\end{array}$ & $\begin{array}{c}\text { weeks } \\
22 \\
8 \\
17 \\
17 \\
17\end{array}$ & $\begin{array}{l}D \\
D \\
S \\
S \\
S\end{array}$ \\
\hline $\begin{array}{l}6 \\
7\end{array}$ & $\begin{array}{l}\text { II } \\
\text { II }\end{array}$ & $\begin{array}{l}F \\
F\end{array}$ & $\begin{array}{l}14 \\
13\end{array}$ & $\begin{array}{l}45 \\
50\end{array}$ & & $\begin{array}{l}30 \\
30\end{array}$ & $\begin{array}{l}\text { B } \\
\text { B }\end{array}$ & & & & $\begin{array}{l}5 \\
7\end{array}$ & $\begin{array}{l}\mathrm{D} \\
\mathrm{D}\end{array}$ \\
\hline $\begin{array}{l}8 \\
9\end{array}$ & $\begin{array}{l}\text { III } \\
\text { III }\end{array}$ & $\begin{array}{l}F \\
F\end{array}$ & $\begin{array}{l}14 \\
13\end{array}$ & $\begin{array}{l}37 \\
24\end{array}$ & $\begin{array}{l}193 \\
143\end{array}$ & $\begin{array}{l}369 \\
254\end{array}$ & $\begin{array}{l}\mathrm{D} \\
\mathrm{D}\end{array}$ & $\begin{array}{l}18 \\
18\end{array}$ & $\begin{array}{l}40 \\
40\end{array}$ & $\begin{array}{l}\text { Macrocytic } \\
\text { Macrocytic }\end{array}$ & $\begin{array}{l}76 \\
76\end{array}$ & $\begin{array}{l}\mathbf{S} \\
\mathbf{S}\end{array}$ \\
\hline $\begin{array}{l}10 \\
11\end{array}$ & $\begin{array}{l}\text { IV } \\
\text { IV }\end{array}$ & $\begin{array}{l}\mathbf{F} \\
\mathbf{F}\end{array}$ & $\begin{array}{l}14 \\
13\end{array}$ & $\begin{array}{l}40 \\
36\end{array}$ & & $\begin{array}{l}29 \\
30\end{array}$ & $\underset{\mathrm{E}}{\mathrm{E}}$ & & & & $\begin{array}{l}8 \\
8\end{array}$ & $\begin{array}{l}\mathrm{D} \\
\mathrm{D}\end{array}$ \\
\hline $\begin{array}{l}12 \\
13\end{array}$ & $\begin{array}{l}\mathrm{V} \\
\mathrm{V}\end{array}$ & $\begin{array}{l}\mathrm{F} \\
\mathrm{F}\end{array}$ & $\begin{array}{l}14 \\
13\end{array}$ & $\begin{array}{l}45 \\
34\end{array}$ & $\begin{array}{r}115 \\
58\end{array}$ & $\begin{array}{l}254 \\
341\end{array}$ & $\begin{array}{l}F \\
F\end{array}$ & $\begin{array}{l}18 \\
15\end{array}$ & $\begin{array}{l}45 \\
28\end{array}$ & $\begin{array}{l}\text { Macrocytic } \\
\text { Macrocytic }\end{array}$ & $\begin{array}{l}76 \\
76\end{array}$ & $\begin{array}{l}\mathbf{S} \\
\mathbf{S}\end{array}$ \\
\hline $\begin{array}{l}14 \\
15\end{array}$ & $\begin{array}{l}\text { VI } \\
\text { VI }\end{array}$ & $\begin{array}{l}\mathrm{F} \\
\mathrm{F}\end{array}$ & $\begin{array}{l}16 \\
21\end{array}$ & $\begin{array}{l}60 \\
55\end{array}$ & 94 & $\begin{array}{r}339 \\
52\end{array}$ & $\stackrel{G}{G}$ & 19 & 21 & Macrocytic & $\begin{array}{r}55 \\
3\end{array}$ & $\begin{array}{l}\mathrm{D} \\
\mathrm{D}\end{array}$ \\
\hline 16 & VII & F & 9 & 36 & & 215 & C & & & & 22 & D \\
\hline
\end{tabular}

$\mathrm{D}=$ died. $\mathrm{S}=$ sacrificed.

* This indicates the time from the beginning of the experiment.

t For determining this point, we arbitrarily established 6 million red cells (approximately average initial value) as a return to normal. Scarborough (21) gives 6.74 million as the average normal red blood count for the pig, and 5 to 9 million as the normal range. Values finally reached by all pigs with macrocytic anemia were: red blood cells 7.5 to 8 million.

Anemias associated with a deficiency of factors of the vitamin B-complex have been reported from many different laboratories ( 1 to 16 ) as occurring in different species of animals. Castle's extrinsic factor required for the treatment of pernicious anemia in man is found in such natural sources of the B-complex as yeast, beef, wheat germ, rice polish, etc. But, as yet, no single synthetic factor an experimental animal. The pig, which stores the pernicious anemia curative factor in its liver, was selected for this study because its hematopoietic response is more nearly like that of the human. Sixteen animals were used in the experiment (see Table I for age, weight, sex, diet, grouping, etc.). The long experimental period, 76 weeks in the case of the pigs with macrocytic 
anemia, served to bring out certain points not previously noted.

\section{EXPERIMENTAL}

Pure-bred Duroc Jersey pigs farrowed at the North Carolina State College Experimental Farm, Raleigh, N. C., were used in this study. They were kept in individual cement-floored, inside pens, each with its own outside run. Wood shavings served as bedding. The animals were fed twice daily and the food consumption was recorded. Hematologic studies were made weekly on a typical animal from each group until significant changes were observed, then all the animals were studied weekly. quantitative measurements and for making fixed smears. Hemoglobin was measured by a Sahli hemoglobinometer which had been standardized. Reticulocyte counts were made on wet preparations stained with brilliant cresyl blue. Mean corpuscular volume and mean corpuscular hemoglobin content were determined by Wintrobe's method (16a).

Diets. The chief problem was one of selecting a diet deficient enough to produce anemia, and yet sufficiently adequate to permit time for its development. A too drastically deficient diet results in death before marked signs or symptoms develop. Both natural and synthetic diets were employed.

TABLE II

Blood changes

\begin{tabular}{|c|c|c|c|c|c|c|c|c|c|c|c|c|c|c|c|c|}
\hline \multirow{2}{*}{$\begin{array}{l}\text { Swine } \\
\text { num- } \\
\text { ber }\end{array}$} & \multirow[t]{2}{*}{ Group } & \multicolumn{3}{|c|}{$\begin{array}{l}\text { Red blood cells } \\
\text { millions }\end{array}$} & \multicolumn{3}{|c|}{$\begin{array}{l}\text { Hemoglobin } \\
\text { grams per cent }\end{array}$} & \multicolumn{3}{|c|}{$\begin{array}{c}\text { Mean } \\
\text { corpuscular } \\
\text { volume } \\
\text { cubic micra }\end{array}$} & \multicolumn{3}{|c|}{$\begin{array}{c}\text { Mean corpuscular } \\
\text { hemoglobin } \\
\text { content } \\
\text { grams } \times 10^{-12}\end{array}$} & \multicolumn{3}{|c|}{ White blood cells } \\
\hline & & Initial & Anemia & Final & Initial & Anemia & Final & Initial & Anemia & Final & Initial & Anemia & Final & Initial & Anemia & Final \\
\hline $\begin{array}{l}1 \\
2 \\
3 \\
4 \\
5\end{array}$ & $\begin{array}{r}\text { I } \\
\text { I } \\
\text { I-A } \\
\text { I-A } \\
\text { I-A }\end{array}$ & $\begin{array}{l}6.51 \\
7.07 \\
7.52 \\
6.99\end{array}$ & $\begin{array}{l}1.85 \\
5.96\end{array}$ & $\begin{array}{l}1.85 \\
5.96 \\
9.0 \\
7.73 \\
9.07\end{array}$ & $\begin{array}{l}12.2 \\
12.0 \\
14.0 \\
12.2\end{array}$ & $\begin{array}{l}3.4 \\
8.4\end{array}$ & $\begin{array}{r}3.4 \\
8.4 \\
18.0 \\
16.6 \\
18.0\end{array}$ & $\begin{array}{l}64 \\
53 \\
60 \\
46\end{array}$ & $\begin{array}{l}48 \\
49\end{array}$ & $\begin{array}{l}48 \\
49 \\
57 \\
61 \\
57\end{array}$ & $\begin{array}{l}19 \\
17 \\
19 \\
17\end{array}$ & $\begin{array}{l}18 \\
14\end{array}$ & $\begin{array}{l}18 \\
14 \\
20 \\
21 \\
20\end{array}$ & $\begin{array}{l}14,843 \\
17,950 \\
14,550 \\
24,900\end{array}$ & $\begin{array}{l}29,950 \\
15,000\end{array}$ & $\begin{array}{l}29,950 \\
15,000 \\
14,150 \\
14,000 \\
14,550\end{array}$ \\
\hline 6 & II & 5.77 & & 6.17 & 10.9 & & 11.2 & 66 & & 62 & 19 & & 18 & 20,000 & & 17,100 \\
\hline $\begin{array}{l}8 \\
9\end{array}$ & $\begin{array}{l}\text { III } \\
\text { III }\end{array}$ & 6.48 & $\begin{array}{l}2.96 \\
2.72\end{array}$ & $\begin{array}{l}8.21 \\
7.92\end{array}$ & 12.1 & $\begin{array}{l}7.4 \\
7.6\end{array}$ & $\begin{array}{l}15.0 \\
14.8\end{array}$ & 61 & $\begin{array}{l}71 \\
97\end{array}$ & $\begin{array}{l}57 \\
61\end{array}$ & 19 & $\begin{array}{l}25 \\
28\end{array}$ & $\begin{array}{l}18 \\
19\end{array}$ & 15,500 & $\begin{array}{l}20,150 \\
19,250\end{array}$ & $\begin{array}{l}14,150 \\
15,000\end{array}$ \\
\hline 10 & IV & 5.29 & & 6.04 & 10.4 & & 11.2 & 70 & & 55 & 19 & & 19 & 17,000 & & 20,000 \\
\hline $\begin{array}{l}12 \\
13\end{array}$ & $\begin{array}{l}\mathrm{V} \\
\mathrm{V}\end{array}$ & 5.07 & $\begin{array}{l}3.93 \\
2.76\end{array}$ & $\begin{array}{l}7.55 \\
7.95\end{array}$ & 10.0 & $\begin{array}{l}9.0 \\
5.0\end{array}$ & $\begin{array}{l}13.0 \\
14.3\end{array}$ & 69 & $\begin{array}{l}81 \\
76\end{array}$ & $\begin{array}{l}60 \\
54\end{array}$ & 20 & $\begin{array}{l}23 \\
24\end{array}$ & $\begin{array}{l}17 \\
18\end{array}$ & 14,900 & $\begin{array}{l}18,000 \\
24,800\end{array}$ & $\begin{array}{l}20,900 \\
14,500\end{array}$ \\
\hline 14 & VI & 8.68 & 5.54 & 8.57 & 14.0 & 14.0 & 16.2 & 51 & 74 & 65 & 16 & 26 & 19 & 19,000 & 23,000 & 19,800 \\
\hline 16 & VII & 7.61 & & 9.0 & 13.6 & & 15.4 & 60 & & 56 & 18 & & 17 & 16,500 & & 26,000 \\
\hline
\end{tabular}

Gastric acidity and stool fat determinations were made periodically. Necropsies were performed on most of the pigs. The findings, however, were not significant as far as the deficiency state was concerned since all the deficient animals living longer than 8 weeks had returned to normal by the end of the experiment.

The weanling pigs, having an average initial weight of $39 \mathrm{lbs}$., used in Groups I to V, inclusive, were paired litter mates. Three heavier animals with average initial weight of 92 lbs. were used in Group I, but because of their very different behavior were designated as Group I-A. The one surviving pig of Group VI was somewhat older and had an initial weight of $60 \mathrm{lbs}$. Pig 16, a young weanling of $36 \mathrm{lbs}$., and thus comparable to those of the first five groups, served as a positive control subsisting on a diet containing brewer's yeast at a level of 10 per cent for 22 weeks.

Blood studies. Blood from the jugular vein was collected in tubes containing potassium oxalate $(2 \mathrm{mgm}$. per cc. of blood drawn). Venous blood was used for all the

\section{Natural diet}

The pigs in Group I were given the following modification of Goldberger's blacktongue-producing diet number 123 of natural foodstuffs (17).

Diet A

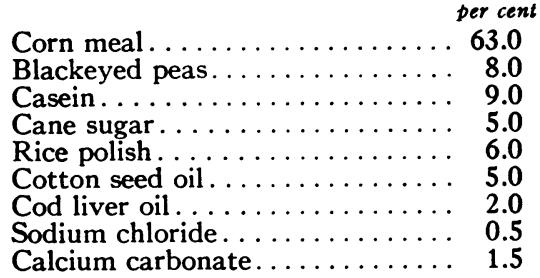

This diet is almost identical with one used by Miller and Rhoads (4) for the production in swine of a mild anemia which was microcytic in some individuals and macrocytic in others. 


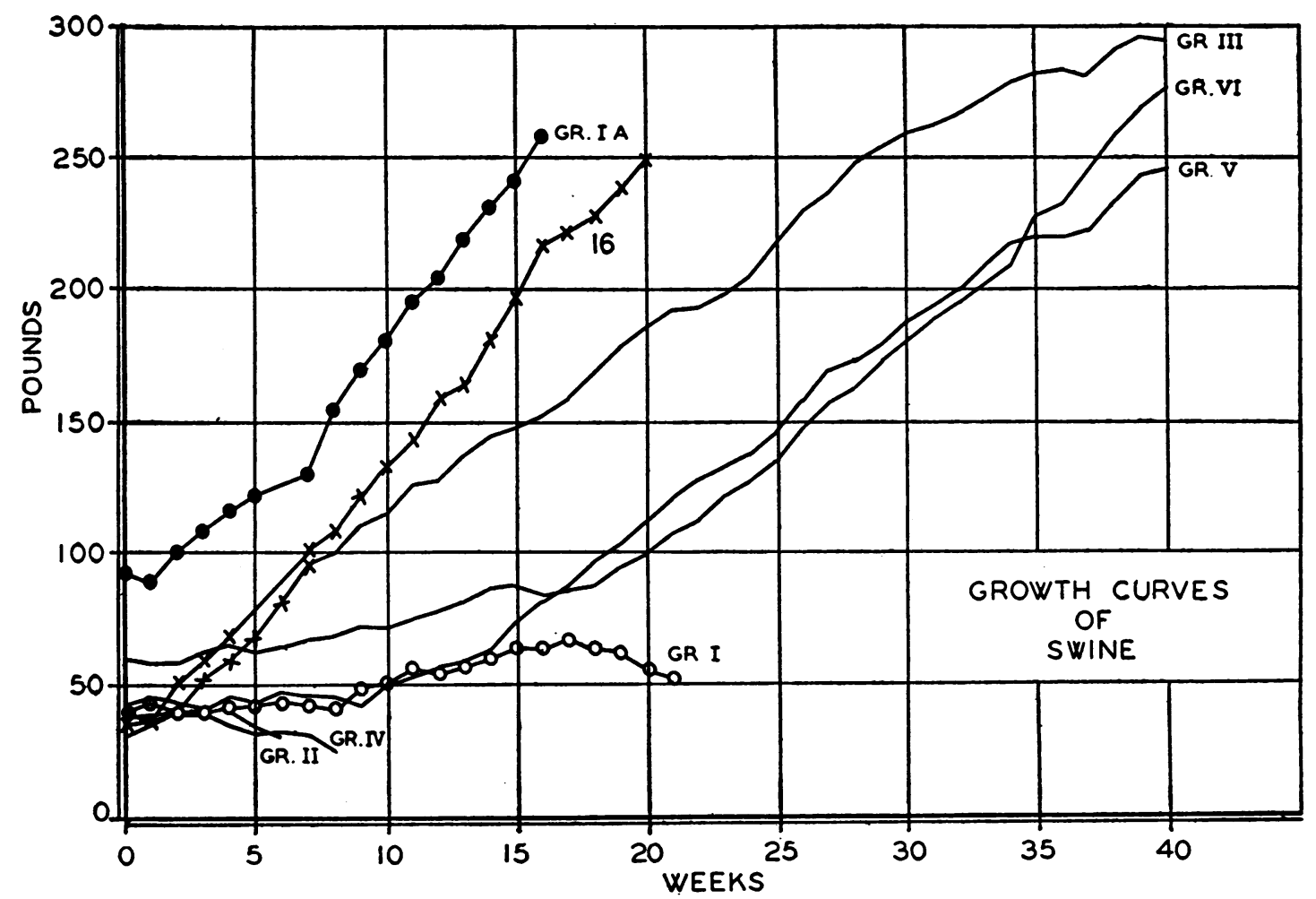

Fig. 1. Growth Curves of Swine on the Following Diets :

Group I, weanling animals on the blacktongue-producing diet; Group I-A, older animals on the same diet; Group II, basal diet (synthetic vitamin B-complex free diet) + vitamin $\mathrm{B}_{1}$; Group III, basal diet + vitamin $B_{1}+$ yeast (4 per cent); Group IV, basal diet + vitamin $B_{1}+$ nicotinic acid + riboflavin; Group $\mathrm{V}$, basal diet + vitamin $\mathrm{B}_{1}+$ rice polish concentrate + yeast (2 per cent) ; Group VI, basal diet + vitamin $\mathrm{B}_{1}+$ yeast ( 3 per cent) ; Pig 16 (positive control), basal diet + yeast (10 per cent).

Among the 5 pigs in Groups I and I-A receiving the diet, results appeared to depend largely on their initial weight. Both of the 2 younger pigs ( 1 and 2 ) developed microcytic anemia, one mild, and the other very severe. The 3 older pigs (3, 4 and 5) failed to develop anemia. The additional weight with the accompanying vitamin storage appeared to protect them against the deficiencies encountered. Further data concerning these animals will be found in Tables I and II and Figure 1.

Gastric analyses indicated free hydrochloric acid in all 5 pigs throughout the experiment.

At necropsy pig 2 showed enlarged and infected lymph nodes at the base of the neck, and small ulcers profusely distributed throughout the large intestine.

\section{Synthetic diets}

The basal diet which served as the foundation for all of the synthetic rations in these experi- ments is essentially vitamin B-complex-free. Its composition follows:

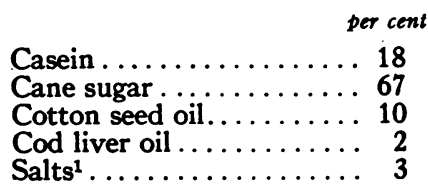

This diet, when supplemented with an adequate source of the vitamin B-complex (brewer's yeast at a level of 10 per cent), was readily consumed,

1 Salt mixture :

percent

Bone meal .............. 57.8

Sodium chloride ............ 24.4

Limestone ............... 12.2

Iron sulfate $\ldots \ldots \ldots \ldots \ldots \ldots \ldots, 3.7$

Magnesium oxide ............ 1.2

Copper sulfate $\ldots \ldots \ldots \ldots \ldots \ldots . . \ldots .3$

Manganese sulfate ........... 0.1

Zinc oxide $\ldots \ldots \ldots \ldots \ldots \ldots \ldots, 0.1$

Cobalt carbonate .............. 0.1

Potassium iodide .............. 0.1 
and resulted in good growth and freedom from anemia in spite of the fact that no provision was made for supplying vitamin $\mathrm{C}$.

To reduce the degree of vitamin B-complex deficiency, supplements of the various factors of the vitamin B-complex in both synthetic and natural form were added to the basal diet as follows:

$\begin{array}{lllllrc}\text { Group } & \text { II } & \text { IV } & \text { V } & \text { VI } & \text { III } & \text { VII } \\ \text { Diet....... } & \text { B } & \text { E } & \text { F } & \text { G } & \text { D } & \text { C }\end{array}$

Daily supplements to the basal diet

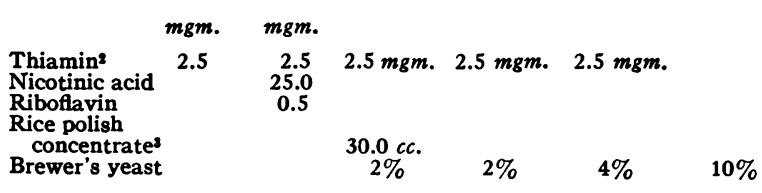

Neither of the diets B or E, having only synthetic vitamin supplements, proved adequate. All pigs on these diets died before anemia developed (Groups II and IV, Table I).

However, natural sources of the vitamin Bcomplex, such as yeast and rice polish concentrate, when fed at the proper level, resulted in a partial prolonged deficiency which served our purpose in producing a macrocytic anemia. It was necessary to adjust the levels of these supplements slightly as the experiment proceeded.

\section{Diets on which macrocytic anemia was produced}

(a) Diet $F$ (basal diet supplemented with rice polish concentrate and brewer's yeast at a 2 per cent level; Group V, Pigs 12 and 13). At the beginning of the experiment no yeast was incorporated in the basal diet and only $15 \mathrm{cc}$. of rice polish concentrate were given. At the end of 8 weeks the daily dose of rice polish concentrate was increased from 15 to $30 \mathrm{cc}$. This resulted in some general improvement but it was insufficient to insure time for the development of anemia. Since the response was not commensurate with the increase in active supplement, the effect was augmented by introducing brewer's yeast into the basal diet at a level of 2 per cent. With these alterations the pigs gained weight and, during a

2 The thiamin used in this study was kindly supplied by Merck and Company, Rahway, New Jersey.

3 A part of the rice polish concentrate (chicken riboflavin test supplement) used was kindly supplied by the Vitab Company, Emeryville, California. period of 15 to 23 weeks, gradually developed a macrocytic anemia (Figure 1, Group V; Figure $3, \mathrm{D}$ and $\mathrm{E})$. Both animals had an occasional steatorrhea. Pig 13 developed achlorhydria, but Pig 12 retained its gastric acidity throughout the experiment. Both pigs developed stiff legs. The blood changes are recorded in Table II.

(b) Diet $G$ (basal diet with brewer's yeast incorporated at a level of 2 to 3 per cent replacing an equivalent amount of sugar; Group VI, Pigs 14 and 15).4 Exact comparisons cannot be made between the different levels of yeast since Pig 14, the surviving pig on this diet, was older and considerably heavier than the pigs on the 4 per cent and 10 per cent levels. The importance of this will be discussed in more detail later because of its bearing on the expected results. Pig 14, a healthy young pig with an initial weight of $60 \mathrm{lbs}$., was given the basal diet alone for 1 week. Yeast was then incorporated into the basal diet at a level of 2 per cent for 15 weeks, when the pig began to vomit and lose weight. It was obvious that the pig could not survive long on this regime. Consequently, the yeast level was raised to 4 per cent for 2 weeks, then reduced to 3 per cent for 19 weeks, to 2 per cent for 11 weeks and to 1 per cent for 3 weeks. Yeast was then completely removed from the diet and the pig died 3 weeks later. The blood changes are recorded in Table II.

Neurologic changes. At the end of 18 weeks this pig had developed stiff legs resulting in a very awkward walk with a tendency to lift the feet rather high. Increased excitability was noted in the animal at this time. The pig seemed to grow gradually more irritable and tense when, during the thirty-first week, it had an epileptiform seizure. This was never repeated, nor were any other neurologic signs noted, but the animal continued to be somewhat more excitable than normal. Shortly before death there was a generalized hemorrhagic diathesis characterized by nose bleed and hemorrhage into the skin. There was no vita$\min \mathrm{C}$ in the diet, and since these symptoms were suggestive of scurvy, large doses of ascorbic acid

4 Pig 15 was obviously not in normal condition at the start of the experiment. It was 21 weeks old and weighed 55 lbs., as compared with 92 lbs., the average weight of other pigs of that age. It developed extreme weakness of the hind legs in $21 / 2$ weeks, became completely paralyzed and died at the end of 3 weeks. 


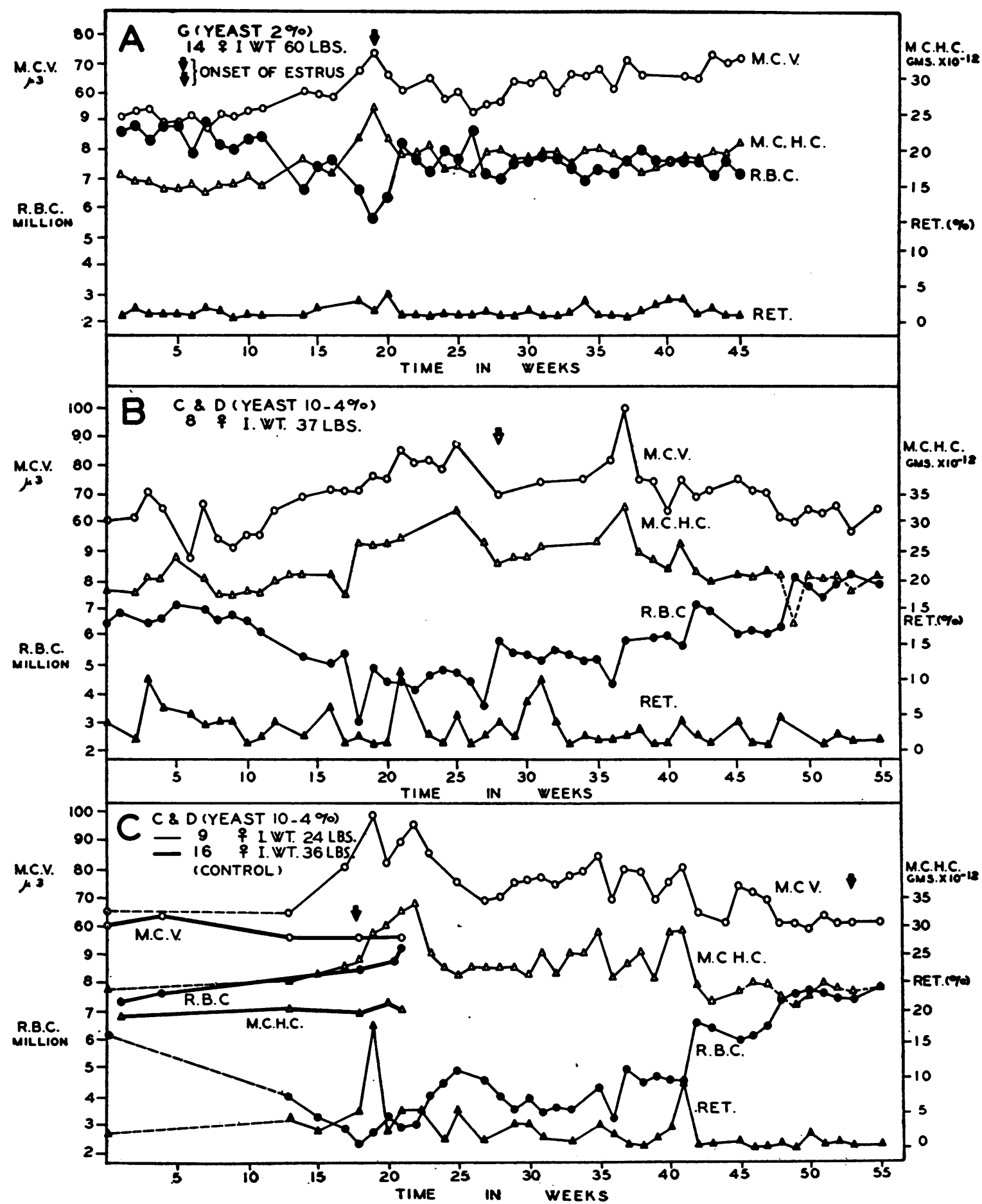

Fig. 2. Charts of the Red Blood Counts, Reticulocytes, Mean Corpuscular Hemoglobin Content and Mean Corpuscular Volume of:

A. Pig. 14, an animal slightly heavier than the others, receiving a synthetic diet with yeast at a level of 3 per cent; B. Pig 8, a lighter animal receiving a similar synthetic diet with yeast at a level of 4 per cent; C. Pig 9 , a light animal comparable to $\mathrm{Pig}$. The hematology chart of $\mathrm{Pig} 16$, positive control receiving yeast at level of 10 per cent, is superimposed for comparison. At this level there is a gradual steady increase in the red cell count, whereas a similar weanling on a 4 per cent level shows a gradual decrease in the red cell count with a subsequent return to normal. 


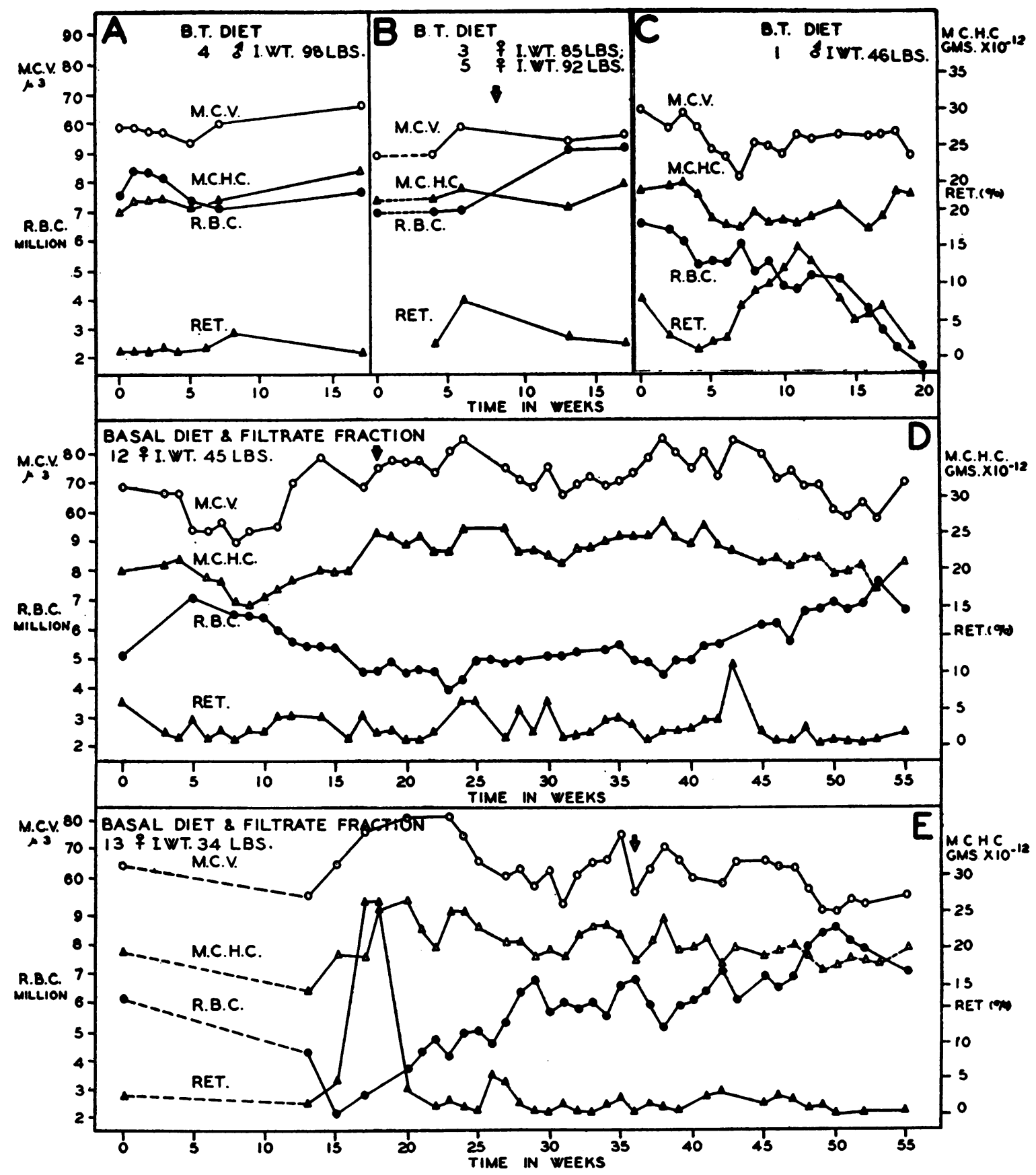

Fig. 3. Charts of the Red Blood Count, Reticulocytes, Mean Corpuscular Hemoglobin Content and Mean Corpuscular Volume of:

A. Pig 4, a slightly heavier male receiving the natural blacktongue-producing diet; B. average values for 2 comparable females (the 3 pigs having an initial weight of $92 \mathrm{lbs}$.) receiving the same diet; C. Pig 1 having an initial weight of $46 \mathrm{lbs}$. on the same blacktongue-producing diet and showing the development of a severe microcytic anemia; D. and E. Pigs 12 and 13, weanlings with initial weights of 45 and $34 \mathrm{lbs}$., receiving the synthetic basal diet + vitamin $B_{1}+$ rice polish concentrate + yeast ( 2 per cent), and showing the development of a macrocytic anemia with subsequent spontaneous recovery. 
were given by mouth and intraperitoneally but without effect. Death due to pneumonia was demonstrated at autopsy.

(c) Diet $D$ (basal diet with yeast incorporated at a level of 4 per cent; Group III, Pigs 8 and 9). These animals consumed a diet containing yeast at a level of 10 per cent (Diet C) for 8 weeks. During this time the pigs appeared normal in every way. The yeast was then decreased from 10 per cent to 4 per cent. Although both pigs continued to grow on this regime at an approximately normal rate, they developed a very severe macrocytic anemia during the subsequent 10 weeks. The blood changes are recorded in $\mathrm{Ta}$ ble II.

Pig 9 developed gastric achlorhydria after about a year on the diet but Pig 8 continued to show free gastric hydrochloric acid throughout the experiment.

\section{Positive control}

(d) Diet $C$ (basal diet with yeast incorporated at a level of 10 per cent; Group VII, Pig 16). Only one animal consumed Diet $C$ for a sufficiently long experimental period to serve as a positive control. Yeast at this level completely protected this pig against the development of anemia. Growth was excellent (Figure 1), the animal remained free from anemia throughout the experiment (Figure 2, C), and initial estrus occurred at the expected time. Blood changes are recorded in Table II.

\section{DISCUSSION}

Four factors affect the results obtained in any nutrition experiment: (1) the degree of deficiency of the diet; (2) the vitamin storage of the animal at the beginning of the experiment; (3) any coincident physiologic stress; (4) the presence of infection. The first is usually determined arbitrarily by the investigator, the second by the age and previous diet of the animal, the third chiefly by age, and the fourth is purely a matter of chance unless infection is induced as a part of the experiment.

In the experiments reported here, the young pigs of Groups III, V, and VI developed a macrocytic anemia which was most acute during and shortly after the period which corresponds roughly to adolescence in the human. This anemia cleared up gradually after time had elapsed for the establishment of normal estrous rhythm and while the animals were still consuming essentially the same diet. Initial estrus occurs in the pigs of the North Carolina State College Experimental Farm at from 20 to 35 weeks of age. Examination of Figure 2, A, B and C and Figure 3, D and E, indicates that the low point of the anemia was reached after 15 to 22 weeks on the experiment when the pigs were between 28 and 35 weeks old.

TABLE III

Relationship of body weight and diet to onset of estrus and development of anemia

\begin{tabular}{|c|c|c|c|c|}
\hline Pig & $\begin{array}{l}\text { Initial } \\
\text { weight }\end{array}$ & $\begin{array}{c}\text { First } \\
\text { estrus }\end{array}$ & Diet & $\underset{\text { anemia }}{\text { Macrocytic }}$ \\
\hline $\begin{array}{c}16 \\
\text { (control) } \\
14 \\
12 \\
8 \\
13 \\
9\end{array}$ & $\begin{array}{l}\text { lbs. } \\
36 \\
60 \\
45 \\
37 \\
34 \\
24\end{array}$ & 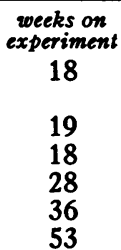 & $\begin{array}{l}\text { Adequate } \\
\text { Inadequate } \\
\text { Inadequate } \\
\text { Inadequate } \\
\text { Inadequate } \\
\text { Inadequate }\end{array}$ & $\begin{array}{c}t \\
++ \\
+++ \\
++t \\
+++t\end{array}$ \\
\hline
\end{tabular}

Pig 14 had additional estrous periods at 23 and 50 weeks; Pig 12 at 53, 61, 67 and 73 weeks; Pig 8 at 36, 40, 58, 61,73 and 77 weeks and, after being placed back in stock, gave birth to a litter of 6 live pigs; Pig 13 at 53 and 74 weeks, and Pig 9 one at 65 weeks. The anemia began to improve gradually after the initial estrus except in Pig 9 where improvement preceded this long delayed initial estrus by a few weeks.

Much evidence indicates that the factors of the vitamin B-complex play a part in maintaining the gonads as well as the hematopoietic system. Concrete evidence of the effect of vitamin B-complex deficiency on the estrous cycle of rats has been offered by Richter and Hawkes (18) in their carefully controlled experiments. These investigators noted that, if from an otherwise adequate diet, yeast, serving as the sole source of the vitamin B-complex, was withdrawn, it resulted in loss of estrus in 14 days and marked atrophy of the ovaries and uterus in 40 days.

If we may assume, then, that the comparatively low level of the vitamin B-complex contained in the diets described above must be shared both by the blood-forming elements and the sex endocrine system, any heightened activity of the latter system will increase its requirement of the vitamin B factors and thus precipitate a more marked deficiency which will be reflected in the former sys- 
tem. One would expect equilibrium to be reestablished only after the strain of the onset of estrus had passed and sexual stability had been established. This is just what occurred. Not only did 5 pigs of Groups III, V and VI develop a macrocytic anemia, but there was a definite postponement of estrus in the 3 pigs having the most severe anemia, namely, Pigs 8, 9 and 13 . Onset of estrus was noted in Pigs 12 and 14 at the expected time. Both these animals were heavier, having an initial weight of 45 and 60 lbs., respectively, as compared with the 37,24 and $34 \mathrm{lbs}$. of the other 3 . This additional weight with the increased vitamin storage could easily account for the greater protection afforded both systems, namely, a much milder anemia and no demonstrable interference with the onset of estrus.

We believe that the macrocytic anemia observed in these animals is the most severe yet produced experimentally in pigs. Undoubtedly, the prolonged partial deficiency of the vitamin B-complex in the diet, the unstable condition of the animals due to their initial age and weight, and the long duration of the experiment all contributed to this result. As one would expect in any macrocytosis, the mean corpuscular volume and mean corpuscular hemoglobin content increased proportionally as the red count fell (Figure 2, A, B and C; Figure $3, \mathrm{D}$ and $\mathrm{E}$ ). The mean corpuscular volume rose to a maximum of 97 cubic micra in Group III and 81 cubic micra in Group V, the maximum mean corpuscular hemoglobin content being 28 $\times 10^{-12}$ grams and $24 \times 10^{-12}$ grams, respectively.

Two other groups of investigators have produced macrocytic anemia experimentally in swine; Miller and Rhoads in 1935 (4) and Wintrobe and his coworkers in 1939 (16b). The former group produced anemia on a diet quite similar to our Diet A. This resulted in microcytic anemia in some individuals and macrocytic in others. The highest mean corpuscular volume reported was 62 cubic micra. Compared with ours, this is low but it represents a significant rise over the initial value of the individual pig. Wintrobe and his associates produced some degree of macrocytosis on synthetic diets similar to ours in which reduced levels of yeast supplied the factors of the vitamin B-complex. The highest mean corpuscular vol- ume reported by these investigators was 68 cubic micra.

The blood smear of Pig 9 of our series showed large numbers of reticulocytes but there was no reason to suspect a hemolytic process this time. There was never any clinical evidence of blood loss or of jaundice, and the giant size of the majority of the reticulocytes makes the presence of a hemolytic process improbable. Pigs which developed macrocytic anemia in similar experiments performed by Wintrobe showed no change in their icteric indices (16a).

All of the mineral elements thought to be concerned in any way with hemoglobin formation, either directly or catalytically, such as iron, copper, manganese, cobalt, etc., were supplied adequately in the salt mixture of the synthetic diets. Therefore, we feel that the anemia produced on the synthetic diets was in no way referable to a mineral deficiency.

Chick and her collaborators (7) found a level of 4 per cent yeast adequate in supplying all the $B$ vitamins required by young pigs (initial weight 51 to $70 \mathrm{lbs}$.) during an experimental period of 9 weeks. Our experience with pigs having an initial weight of 24 to 37 lbs. observed over a 76week experimental period indicates that, although approximately normal growth ensues, this level of yeast does protect against the development of macrocytic anemia. Our positive control pig tested for a period of 22 weeks showed excellent growth, well-being, and freedom from anemia, and exhibited an improvement in the blood during this period, indicating that a level of 10 per cent brewer's yeast was adequate to maintain the bloodforming elements in this pig. Since levels between 4 per cent and 10 per cent were not tried, we do not know the minimum protective level for a pig of this weight (35 to 40 lbs.).

Smith and Otis (19) have presented evidence that female rats use low levels of iron in the diet more efficiently for hemoglobin building than do males. In this connection it is interesting that, of the 3 animals in Group I-A, the one male increased his hemoglobin from 14 to 16 grams during the experimental period, while the 2 females increased theirs from 12 to 18 grams (average values) during the same period. The number of 
animals used, however, is much too small to draw conclusions.

All the neurologic symptoms noted in our animals have been observed previously by others $(4,7,16 \mathrm{~b})$. The occurrence of one epileptiform seizure in Pig 14 parallels the experience of Chick and her collaborators who observed sporadic seizures in pigs on a borderline level of vitamin $B_{6}$. Where the $B_{6}$ deficiency was more acute, the seizures increased in number and intensity until the eluate fraction supplying the $B_{6}$ was administered. A diet in which yeast at a level of 2 to 3 per cent supplies the B-factors results in a borderline level of vitamin $\mathrm{B}_{6}$ and explains the occurrence of only one such seizure in our animal.

\section{SUMMARY AND CONCLUSIONS}

A severe macrocytic anemia was produced in weanling pigs on a prolonged partial deficiency of the vitamin B-complex.

Brewer's yeast at a level of 4 per cent was not adequate under the conditions of these experiments to protect weanling pigs (weighing $45 \mathrm{lbs}$. or less) from developing macrocytic anemia. A 10 per cent level of yeast, however, was quite satisfactory for this purpose in the one animal tested for 22 weeks.

Spontaneous cure of the anemia ensued while the pigs remained on the same diet and without treatment.

A possible explanation for the development of anemia on a diet which later is adequate for its cure is offered in the physiological stress and strain preceding sexual maturity, which apparently corrects itself after sexual stability is accomplished.

\section{ACKNOWLEDGMENTS}

We wish to thank Mr. Preston Smith for his valuable aid in the hematologic studies and Mr. Tom Lassater for his careful work with the diets.

Dr. Frederick M. Hanes, Professor of Medicine, Duke University School of Medicine, Durham, N. C. and Dr. Earl H. Hostetler, Professor of Animal Husbandry at North Carolina State College, Raleigh, N. C. gave invaluable aid by their timely advice and encouragement throughout the course of this study.

\section{BIBLIOGRAPHY}

1. Whitehead, R. W., and Barlow, O..W., Studies on the anemia of rice disease in rats. The influence of vitamins A, B, D, iron, copper, beef muscle, and liver on the course and regeneration from the anemia of rice disease. Am. J. Physiol., 1929, 89, 542.

2. Sure, B., Kik, M. C., and Smith, M. E., Hematopoietic function in avitaminosis. VI. Vitamin G deficiency. Proc. Soc. Exp. Biol. and Med., 1931, 28, 498.

3. Rhoads, C. P., and Miller, D. K., The production in dogs of chronic blacktongue with anemia. J. Exper. Med., 1933, 58, 585.

4. Miller, D. K., and Rhoads, C. P., The experimental production of loss of hematopoietic elements of the gastric secretion and of the liver in swine with achlorhydria and anemia. J. Clin. Invest., 1935, 14, 153.

5. Spies, T. D., and Dowling, A. S., The experimental production of anemia in dogs by means of a blacktongue-producing diet. Am. J. Physiol., 1935, 114, 25.

6a. Day, P. L., Langston, W. C., and Shukers, C. F., Leukopenia and anemia in the monkey resulting from vitamin deficiency. J. Nutrition, 1935, 9, 637.

b. Day, P. L., and others, Nutritional cytopenia in monkeys receiving the Goldberger diet. J. Exper. Med., 1940, 72, 463.

7. Chick, H., and others, The water-soluble B-vitamins other than aneurin (vitamin $B_{1}$ ), riboflavin and nicotinic acid required by the pig. Biochem. J., 1938, 32, 2207.

8. Ungley, C. C., The effect of yeast and wheat embryo in anaemias. I. Marmite, yestamin, and bemax in megalocytic and nutritional hypochromic anaemias. Quart. J. Med., 1933, 2, 381.

9. Davidson, L. S. P., Autolysed yeast products in the treatment of anaemia. Brit. Med. J., 1933, 2, 481.

10. Russell, H. K., Hematological response of Addisonian pernicious anemia to brewer's yeast. Ann. Int. Med., 1934, 7, 1398.

11a. Fouts, P. J., and others, Production of microcytic hypochromic anemia in puppies on synthetic diet deficient in rat antidermatitis factor (vitamin $B_{6}$ ). J. Nutrition, 1938, 16, 197.

b. Fouts, P. J., Helmer, O. M., and Lepkovsky, S., Nutritional microcytic hypochromic anemia in dogs cured with crystalline Factor I. Am. J. M. Sc., 1940, 199, 163.

12. Wills, L., and Stewart, A., Experimental anaemia in monkeys, with special reference to macrocytic nutritional anaemia. Brit. J. Exp. Path., 1935, 16, 444.

13. Hogan, A. G., Richardson, L. R., and Johnson, P. E., A new deficiency disease associated with the vitamin B complex. J. Biol. Chem. (Proc.), 1937, 119, 1.

14. Heinle, R. W., and Miller, F. R., Yeast as an extrinsic factor in relation to pernicious anemia. $\mathrm{J}$. Clin. Invest., 1939, 18, 257.

15. Gyorgy, P., and others, Panmyelophthisis with hemorrhagic manifestations in rats on a nutritional basis. J. Exper. Med., 1937, 66, 579. 
16a. Wintrobe, M. M., Size and hemoglobin content of the erythrocyte: methods of determination and clinical application. J. Lab. and Clin. Med., 1932, 17, 899.

b. Wintrobe, M. M., Samter, M., and Lisco, H., Morphologic changes in the blood of pigs associated with deficiency of water-soluble vitamins and other substances contained in yeast. Bull. Johns Hopkins Hosp., 1939, 64, 399.

17. Goldberger, J., and others, A further study of experimental blacktongue with special reference to the blacktongue preventive in yeast. U. S. Pub. Health Reports, 1928, 43, 657.

18. Richter, C. P., and Hawkes, C. D., The dependence of carbohydrate, fat and protein, appetite of rats on various components of the vitamin B-complex. Am. J. Physiol., 1941, 131, 639.

19. Smith, M. C., and Otis, L., Sex variations in the utilization of iron by anemic rats. Science, 1937, 85, 125.

20. Scarborough, R. A., The blood picture of normal laboratory animals. Yale J. Biol. and Med., 1930, 3, 547. 